\title{
Replacing human-edible feed ingredients with by-products increases net food production efficiency in dairy cows
}

\section{Johanna Karlsson, ${ }^{1}$ Rolf Spörndly, Mikaela Lindberg, and Kjell Holtenius}

Department of Animal Nutrition and Management, Swedish University of Agricultural Sciences, Box 7024, SE-750 07 Uppsala, Sweden

\begin{abstract}
Global demand for food is increasing, and use of large amounts of potentially human-edible feedstuffs for dairy cows is an important concern. The present study examined whether feeding a by-product-based concentrate combined with high-quality grass silage to high-producing dairy cows affected feed intake and milk production compared with a conventional diet, as well as the effect on efficiency of human food production. In a changeover experiment with four 21-d periods, 24 dairy cows in mid-lactation were offered $9.6 \mathrm{~kg}$ of dry matter per day with 1 of 4 concentrates and highquality grass silage ad libitum. The control concentrate was based on cereal grain (wheat, oat, and barley) and soybean meal, whereas the 3 by-product-based concentrates contained sugar beet pulp in combination with mainly heat-treated rapeseed meal, distillers grain, or a mixture of both. All diets were formulated to be isoenergetic and isonitrogenous. The cows had 10-fold higher starch intake when fed the control diet than when fed the by-product-based concentrates. Silage intake (13 kg of dry matter/d) and milk production (33 kg of energy-corrected milk/d) were not affected by the change in diet. Therefore, replacing cereals and soybean meal with human-inedible by-products in a high-quality forage diet to dairy cows increased net food protein production substantially without lowering milk production.
\end{abstract}

Key words: forage, distillers grain, rapeseed meal, sugar beet pulp

\section{INTRODUCTION}

Agriculture, forestry, and other land uses contribute $24 \%$ of total global greenhouse gas emissions (IPCC, 2014). Agriculture uses $38 \%$ of the planet's ice-free land and is the major contributing factor to biodiversity loss, eutrophication, and water use (Foley et al., 2011).

Received November 28, 2017.

Accepted April 9, 2018.

${ }^{1}$ Corresponding author: johanna.karlsson@slu.se
Reducing on-farm, storage, and retail waste has been suggested as a strategy to increase agricultural resource efficiency and, thus, food availability (Foley et al., 2011). A way to reduce waste and increase efficiency could be to challenge existing feeding regimens, where large volumes of human-edible products such as cereal grain (CG; wheat, oat, and barley) and soybean meal (SBM) are fed to dairy cows in intensive production systems (Eisler et al., 2014).

According to FAO (2011), future increases in demand for livestock products will occur due to a growing human population and a greater per capita income. As limited possibilities exist to increase the area of arable land, the increase has to rely on an increase in crop yield per hectare. Interests that compete for existing arable land include food, feed, and fuel. With more than $70 \%$ of global agricultural land already being used to produce feed for livestock (FAO, 2009), using human-inedible products as animal feed is becoming increasingly important. One option to produce highquality food more efficiently is to increase the use of by-products from the human food, fiber, and bio-fuel industries in the diet of dairy cows at the expense of human edibles.

Wilkinson (2011) concluded that dairy production is the most efficient animal production system in the United Kingdom based on the ratio of human-edible input to output. The term net food production (human-edible output minus human-edible input) was introduced by Ertl et al. (2016) to produce a value based on the same input as for human-edible feed conversion efficiency calculated as output-to-input (HeFCE). Byproduct-based concentrates increase net food production of dairy products compared with CG and pulses in organic production (Ertl et al., 2015, 2016). Net food production and $\mathrm{HeFCE}$ are features related to gross energy (GE) and CP. However, estimations of the net production of human digestible EAA by cattle might be a more precise measure (Patel et al., 2017a).

The effects of different feeds on milk production in dairy cattle have been compared in many studies. Numerous by-products are available globally. The byproducts rapeseed meal (RSM), dried distillers grains with solubles (DDGS), and sugar beet pulp (SBP) 
were selected in the present study and are commonly used ingredients in many dairy cow diets, but usually in combination with CG. Previous studies have investigated the effect on milk production and feed intake of replacing protein feed SBM with either RSM (Huhtanen et al., 2011; Martineau et al., 2013) or DDGS (Schingoethe et al., 2009). The effect of partly replacing CG with $\mathrm{SBP}$ as a nutrient source for dairy cows has also been studied (Bhattacharya and Sleiman, 1971; Voelker and Allen, 2003; Whelan et al., 2017). However, studies of complete removal of starch-rich CG from the diet of high-yielding dairy cows are apparently rare. Therefore, the present study examined whether feeding a by-product-based concentrate combined with high-quality grass silage to high-producing dairy cows affected feed intake and milk production compared with a conventional diet and whether it altered the efficiency of human food production.

\section{MATERIALS AND METHODS}

The study was conducted at the Swedish Livestock Research Centre, Uppsala, Sweden, from November 2015 to February 2016. The study was approved by the Uppsala Ethics Committee for Animal Research, Uppsala, Sweden (diary number C98/15).

\section{Experimental Design and Animals}

The study included 12 multiparous and 12 primiparous dairy cows in mid-lactation [on average 85 DIM
$(\mathrm{SD}=13)$ at the start of the study] of the breeds Swedish Holstein $(\mathrm{n}=8)$ and Swedish Red $(\mathrm{n}=16)$. Cows were housed in an insulated loose housing barn. The experimental design was a changeover study with 4 dietary treatments and 4 periods. The cows were blocked by breed and parity, and then randomly assigned to the 4 treatment groups (6 cows per group). At the start of the study, average daily milk yield was $38.6 \mathrm{~kg}$ ( $\mathrm{SD}=$ $8.5)$, average $\mathrm{BW}$ was $644 \mathrm{~kg}(\mathrm{SD}=67)$, and average BCS (Edmonson et al., 1989) was $3.4(\mathrm{SD}=0.3)$. Each of the 4 experimental periods lasted for $3 \mathrm{wk}$. The first 2 wk in each period were used for adaptation to the feed and the last week was used for data collection and sampling. After the end of each experimental period, the groups changed treatment and the concentrate was changed gradually during the first $4 \mathrm{~d}$ in each adaptation period.

\section{Diets and Feeding}

Chemical composition of silage and concentrates is shown in Table 1. All cows had free access to grass silage. The silage was preserved in round bales and fed as a mixture of two-thirds first cut and one-third second cut of a perennial grass sward of timothy (Phleum pratense L.), perennial ryegrass (Lolium perenne L.), tall fescue hybrid (Festulolium pabulare), and tall fescue (Festuca arundinacea Schreb.).

The 4 different concentrates were CG-SBM (control), SBP-DDGS, SBP-RSM, and SBP-RSM-DDGS (byproduct treatments; Table 2). The concentrates were

Table 1. Chemical composition ${ }^{1}$ (means $\pm \mathrm{SD}$ ) of the grass silage and concentrate used in diets fed to dairy cows ( $\mathrm{g} / \mathrm{kg}$ of DM, unless otherwise stated)

\begin{tabular}{|c|c|c|c|c|c|}
\hline Item & Silage & $\begin{array}{c}\text { Cereal grain, } \\
\text { soybean meal } \\
\text { (CG-SBM; control) }\end{array}$ & $\begin{array}{l}\text { Sugar beet pulp, } \\
\text { distillers grain } \\
\text { (SBP-DDGS) }\end{array}$ & $\begin{array}{l}\text { Sugar beet pulp, } \\
\text { rapeseed meal } \\
\text { (SBP-RSM) }\end{array}$ & $\begin{array}{l}\text { Sugar beet pulp, } \\
\text { rapeseed meal, } \\
\text { distillers grain } \\
\text { (SBP-RSM-DDGS) }\end{array}$ \\
\hline $\mathrm{CP}$ & $132 \pm 1$ & $187 \pm 7$ & $192 \pm 2$ & $187 \pm 2$ & $187 \pm 6$ \\
\hline Ether extract & $23 \pm 0$ & $54 \pm 1$ & $79 \pm 2$ & $71 \pm 3$ & $71 \pm 2$ \\
\hline NDF & $460 \pm 2$ & $144 \pm 8$ & $320 \pm 5$ & $339 \pm 3$ & $338 \pm 6$ \\
\hline Ammonia-nitrogen & $1 \pm 0$ & ND & ND & ND & ND \\
\hline VFA & $44 \pm 4$ & ND & ND & ND & ND \\
\hline Ethanol & $5 \pm 1$ & ND & ND & ND & ND \\
\hline Calcium & $4.1 \pm 0.1$ & $12.7 \pm 0.3$ & $5.7 \pm 0.1$ & $6.7 \pm 0.1$ & $5.9 \pm 0.1$ \\
\hline Potassium & $29.1 \pm 0.2$ & $8.8 \pm 0.3$ & $8.9 \pm 0.0$ & $8.8 \pm 0.1$ & $8.9 \pm 0.1$ \\
\hline Magnesium & $1.1 \pm 0.0$ & $4.0 \pm 0.1$ & $4.3 \pm 0.0$ & $3.7 \pm 0.1$ & $3.7 \pm 0.1$ \\
\hline
\end{tabular}

${ }^{1}$ Four samples of each feed were analyzed for chemical composition.

${ }^{2}$ Water-soluble carbohydrates (WSC).

${ }^{3} \mathrm{ND}=$ not determined. 
Table 2. Ingredients in the dairy cow diets and estimated proportion of human edibles according to Wilkinson (2011)

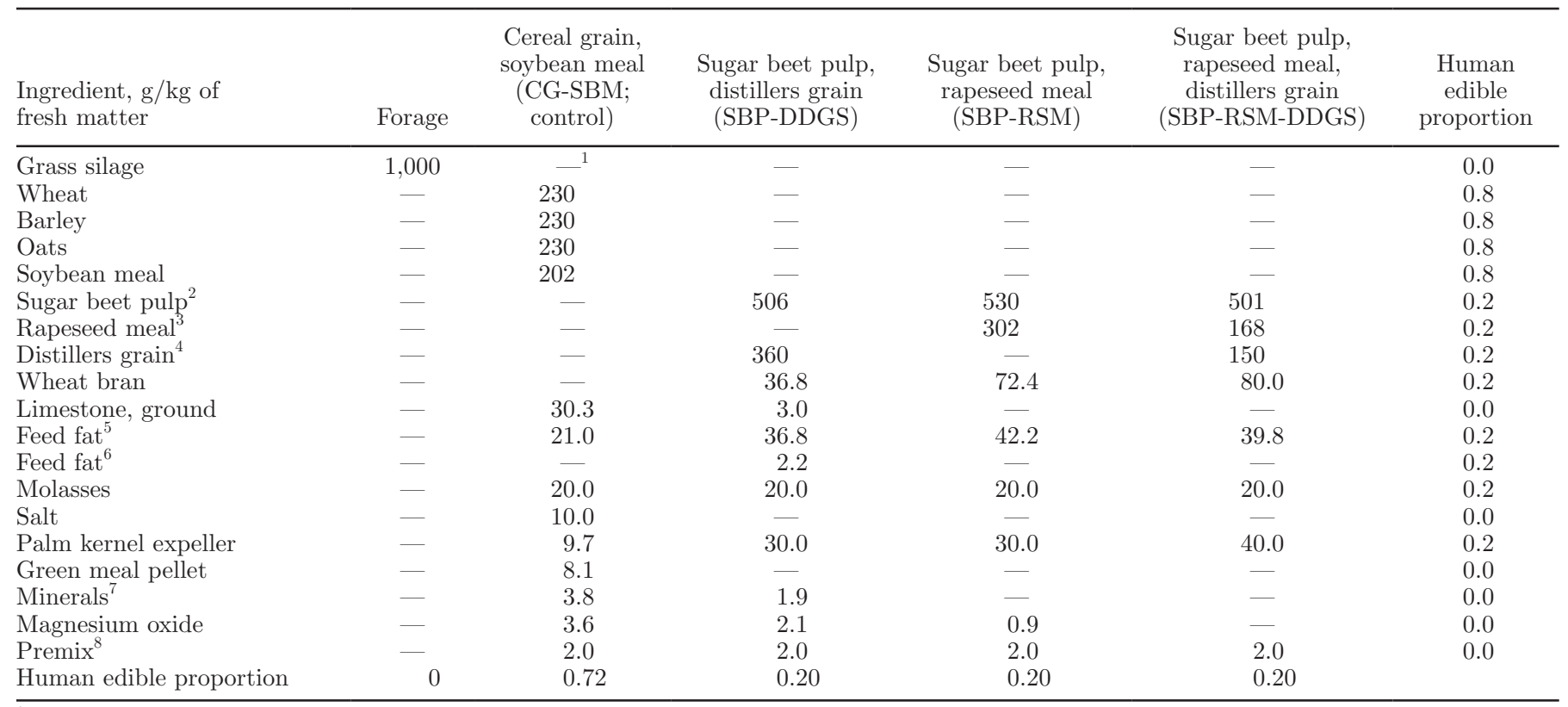

${ }^{1}$ No inclusion.

${ }^{2}$ Dried with no inclusion of molasses (Nordic Sugar AB, Eslöv, Sweden).

${ }^{3}$ Solvent-extracted and heat-moisture treated rapeseed meal with low levels of glucosinolates and erucic acid (ExPro, AAK Sweden AB, Karlshamn, Sweden).

${ }^{4}$ Fiber and yeast cells from ethanol manufacturing (Agrow Drank 90, Lantmännen Agroetanol, Norrköping, Sweden).

${ }^{5}$ Fatty acids (99\% fat; $45 \%$ C16:0, 37\% C18:1).

${ }^{6}$ Fatty acids (99\% fat; 40-55\% C16:0, 40-55\% C18:0, max 8\% C18:1).

${ }^{7}$ Containing 23\% P, $16 \% \mathrm{Ca}$, and 1\% Mg (Bolifor MCP-F, Yara International ASA, Oslo, Norway).

${ }^{8}$ Containing minerals, vitamins, and trace elements.

pelleted and fed individually in concentrate dispensers (FSC400, DeLaval International AB, Tumba, Sweden), restricted to $7.8 \mathrm{~kg}$ of $\mathrm{DM}$ per day. All cows were also offered $1.7 \mathrm{~kg}$ of $\mathrm{DM} / \mathrm{d}$ of concentrate by dispensers in the milking station. However, the dispensers in the milking station could only handle 2 different feeds; therefore, SBP-RSM-DDGS was given to all cows except the cows in the CG-SBM treatment when fed in the milking station. In total, the cows were given $9.6 \mathrm{~kg}$ of $\mathrm{DM} / \mathrm{d}$ of concentrate. When designing the concentrates we were aiming for balancing content of $\mathrm{CP}$ and ME.

\section{Recordings and Sampling}

Individual daily forage intake was recorded automatically (CRFI, BioControl Norway As, Rakkestad, Norway), as was daily concentrate intake (DelPro, DeLaval International AB). Forage intake equipment was calibrated weekly, and concentrate feeding stations were calibrated before the start of the experiment and monthly thereafter. The cows were automatically weighed every time they passed through a sorting gate when leaving the feeding area, and mean daily BW was recorded (AWS100, DeLaval International AB). The weighing scale was calibrated before the start of the experiment. Mean BW per period and at the start of the experiment was calculated from the recordings of BW during the sampling weeks and in the week before the experiment started, respectively. Body condition scoring was performed automatically with a 3-dimensional camera (DeLaval International AB) every time the cows left the milking station. The daily score from the last day of each experimental period was used in the present study, together with the daily score from the day before the experiment started as initial BCS. Silage was sampled 5 times a week, whereas the concentrates were sampled once a week, and both were pooled within period for analysis of chemical composition. All feed samples were collected in plastic bags and stored at $-20^{\circ} \mathrm{C}$ until analysis. Spot samples of feces for estimation of digestibility were collected once a day on 3 consecutive days in each sampling period. The feces were stored at $-20^{\circ} \mathrm{C}$ until pooled per period 
and analyzed. The cows were milked voluntarily in a single-station automatic milking system (VMS, DeLaval International $A B$ ) with the FeedFirst cow traffic system, which resulted in 2.5 milkings per day $(\mathrm{SD}=$ $0.6)$. The system used for identifying the individual cows was certified by the International Organization for Standardization (Geneva, Switzerland). At each milking, the milk yield was recorded. Milk sampling was carried out at all milkings for $24 \mathrm{~h}$ in the middle of the sampling week in each experimental period. The equipment used for milk sampling and measuring milk yield was certified by the International Committee for Animal Recording (Rome, Italy). Milk samples were preserved with bronopol, stored at $8^{\circ} \mathrm{C}$ and analyzed within $3 \mathrm{~d}$.

\section{Chemical Analysis and Calculations}

All analyses were performed by the laboratory at the Department of Animal Nutrition and Management, Swedish University of Agricultural Science, Uppsala, Sweden. The DM content of the forage was determined by first drying at $60^{\circ} \mathrm{C}$ overnight, ground, and then at $60^{\circ} \mathrm{C}$ overnight according to Åkerlind et al. (2011). The DM content of the concentrate was determined by drying at $103^{\circ} \mathrm{C}$ overnight, whereas the DM content of the feces was determined by freeze drying. Ash content for feeds and feces was determined by ignition at $550^{\circ} \mathrm{C}$ for $3 \mathrm{~h}$. All feeds and feces samples were also analyzed for acid-insoluble ash (AIA) according to Van Keulen and Young (1977). Feeds and feces were analyzed for CP by an automated Kjeldahl procedure (Foss, Hillerød, Denmark) and ether extracts according to Commission Directive 98/64/EC (European Economic Community, 1998). The concentrates were analyzed enzymatically for starch (including maltodextrin) according to Larsson and Bengtsson (1983). Both feed and feces were analyzed for NDF according to Chai and Udén (1998), and silage was analyzed for water-soluble carbohydrates according to Larsson and Bengtsson (1983). The silage samples were pressed and the silage juice was analyzed for $\mathrm{pH}$, ammonia-nitrogen, VFA, and ethanol. Ammonia-nitrogen was analyzed according to Broderick and Kang (1980), whereas VFA and ethanol were determined according to Ericson and André (2010). Metabolizable energy content in the concentrates was calculated from tabulated values according to the Swedish Board of Agriculture (SJVFS, 2011). Metabolizable energy content in the silage was estimated by the $96-\mathrm{h}$ in vitro digestible OM (VOS) method, as described by Åkerlind et al. (2011):

$\mathrm{ME}(\mathrm{MJ} / \mathrm{kg}$ of $\mathrm{OM})=0.160 \times \operatorname{VOS}(\%)-1.91$.
Metabolizable energy was then converted to megajoules per kilogram of DM. The samples of feces were thawed and then pooled into 1 sample per cow and period. The pooled samples were again stored at $-20^{\circ} \mathrm{C}$ until freezedried, milled, and analyzed for DM, ash, NDF, CP, and AIA. The total amount of feces was calculated from the total intake of AIA and the content of AIA in the feces (Van Keulen and Young, 1977). Apparent organic matter digestibility was calculated from estimated intake and excretion of $\mathrm{OM}$ from feed and feces as $\left(\mathrm{OM}_{\text {feed }}\right.$ $\left.-\mathrm{OM}_{\text {feces }}\right) / \mathrm{OM}_{\text {feed }}$. Similarly, apparent digestibility of NDF and CP were calculated. The calculations were based on feces samples taken once daily on 3 consecutive days and intake data from the 3 feces sampling days and the preceding day. Milk samples were analyzed for composition of fat, protein, and lactose by infrared Fourier transform spectroscopy (CombiScope FTIR 300 HP, Delta Instruments B.V., Drachten, the Netherlands). Milk composition data from the 24-h samplings were weighed to obtain a daily mean for each cow and period. Energy-corrected milk was calculated based on fat, protein, and lactose content. Gross energy content in megajoules of the milk was estimated as 3.14 times ECM (Sjaunja et al., 1990). Energy intake was calculated in the NorFor system (Volden and Nielsen, 2011).

The proportion of potential human edibles in feeds was calculated according to the broad classification of Wilkinson (2011). Sugar beet pulp, feed fat, and molasses were categorized as other by-products, with an estimated human-edible proportion of 0.2 (Table 2). Human-edible feed conversion efficiency for $\mathrm{CP}$ and GE was calculated as the human-edible content in the milk that the cows produced divided by the potential human-edible content of the feeds that the cows consumed. Net food production (as MJ of GE/d and $\mathrm{kg}$ of $\mathrm{CP} / \mathrm{d}$ ) was calculated as the human-edible content in the milk minus the potential human-edible amount in the feed consumed, according to Ertl et al. (2016). Data on the GE content of the feedstuffs were retrieved from the Feedipedia database (INRA et al., 2016) and data on the GE content of milk from the nutritional database of USDA (2016). Amount of human-digestible essential amino acids (HDEAA) was calculated according to Patel et al. (2017a). Calculations of HDEAA were based on AA concentrations and their true ileal digestibility in pigs (CVB Feed Table, 2011). True ileal digestibility of AA in pigs can be used when values in humans are not available (FAO, 2013). For all production efficiency calculations, only the feed consumed and the milk produced during the experimental period were considered, whereas the feed for rearing the cows to reproductive age and the meat produced from the cows were not considered. 
Table 3. Treatment effects on daily intake and digestibility for the 4 different concentrates (LSM with SEM and $P$-value)

\begin{tabular}{|c|c|c|c|c|c|c|}
\hline \multirow[b]{2}{*}{ Item } & \multicolumn{4}{|c|}{$\operatorname{Diet}^{1}$} & \multirow[b]{2}{*}{ SEM } & \multirow{2}{*}{$\begin{array}{c}P \text {-value } \\
\text { Treatment }\end{array}$} \\
\hline & $\begin{array}{c}\text { CG-SBM } \\
\text { (control) }\end{array}$ & SBP-DDGS & SBP-RSM & SBP-RSM-DDGS & & \\
\hline \multicolumn{7}{|l|}{ Intake, $\mathrm{kg} / \mathrm{d}$} \\
\hline Silage, DM & 13.3 & 12.8 & 13.2 & 13.9 & 0.57 & 0.202 \\
\hline Total DM & 22.9 & 22.4 & 22.7 & 23.5 & 0.57 & 0.202 \\
\hline $\mathrm{OM}$ & 20.9 & 20.6 & 21.0 & 21.7 & 0.52 & 0.157 \\
\hline Ether extract & $0.83^{\mathrm{c}}$ & $1.06^{\mathrm{a}}$ & $0.99^{\mathrm{b}}$ & $1.01^{\mathrm{b}}$ & 0.01 & $<0.001$ \\
\hline Starch & 3.96 & 0.38 & 0.36 & 0.32 & $\mathrm{NE}^{2}$ & $\mathrm{NE}$ \\
\hline Energy, MJ of $\mathrm{NE}_{\mathrm{L}} / \mathrm{d}$ & 153 & 147 & 147 & 151 & 3.0 & 0.053 \\
\hline \multicolumn{7}{|l|}{ Digestibility, \% } \\
\hline OM & $71.6^{\mathrm{a}}$ & $71.1^{\mathrm{a}}$ & $69.9^{\mathrm{b}}$ & $70.1^{\mathrm{b}}$ & 0.43 & 0.001 \\
\hline $\mathrm{NDF}$ & $57.2^{\mathrm{b}}$ & $66.4^{\mathrm{a}}$ & $65.2^{\mathrm{a}}$ & $65.4^{\mathrm{a}}$ & 0.85 & $<0.001$ \\
\hline $\mathrm{CP}$ & $67.6^{\mathrm{a}}$ & $62.0^{\mathrm{b}}$ & $61.3^{\mathrm{b}}$ & $60.8^{\mathrm{b}}$ & 0.81 & $<0.001$ \\
\hline
\end{tabular}

${ }^{\mathrm{a}-\mathrm{c}}$ Means within rows with different superscripts differ significantly $(P<0.05)$.

${ }^{1} \mathrm{CG}=$ cereal grain; $\mathrm{SBM}=$ soybean meal; $\mathrm{SBP}=$ sugar beet pulp; DDGS $=$ distillers grain; $\mathrm{RSM}=$ rapeseed meal.

${ }^{2} \mathrm{NE}=$ not estimated.

\section{Statistical Analyses}

The data were analyzed by PROC MIXED in SAS (version 9.4, SAS Institute Inc., Cary, NC) using a changeover model with the effects of treatment, period, order, and cow as random variable. The model was

$$
\mathrm{Y}_{\mathrm{ijk} \mathrm{k}}=\mu+\mathrm{B}_{\mathrm{i}}+\mathrm{C}_{\mathrm{j}}\left(\mathrm{B}_{\mathrm{i}}\right)+\mathrm{P}_{\mathrm{k}}+\mathrm{T}_{\mathrm{l}}+\varepsilon_{\mathrm{ijk} \mathrm{l}},
$$

where $Y_{\mathrm{ijk}}$ is the dependent variable, $\mu$ is the overall mean, $B_{i}$ is the effect of block $i, C_{j}\left(B_{i}\right)$ is the effect of cow $\mathrm{j}$ within block $\mathrm{i}, \mathrm{P}_{\mathrm{k}}$ is the effect of period $\mathrm{k}, \mathrm{T}_{1}$ is the effect of treatment 1 , and $\varepsilon_{\mathrm{ijk}}$ is the random error. All interactions were estimated, but were removed from the final model because they were not significant. Differences were considered significant at $P<0.05$. The entire herd was infected by bovine respiratory syncytial virus during the sampling week in period 3 . Three cows in the study were housed separately during that week, and therefore all data on those 3 animals ( 2 on treatment SBP-RSM, 1 on SBP-RSM-DDGS) in period 3 were removed from the statistical analyses.

\section{RESULTS}

The content of starch was lower and the content of NDF was higher in the by-product-based concentrates compared with the control CG-SBM (Table 1). The content of $\mathrm{CP}$ was $5 \mathrm{~g} / \mathrm{kg}$ of DM higher in the concentrate SBP-DDGS compared with the other concentrates. All cows, regardless of treatment, consumed their concentrate ration. As can be seen from Table 3, silage intake did not differ between treatments; how- ever, starch intake was about 10-fold higher for the CG-SBM concentrate than for the by-product-based concentrates, whereas NDF intake was lower for the CG-SBM concentrate than for the by-product-based concentrates. The RSM-containing diets had lower OM digestibility and the by-product-based diets had higher NDF and lower CP digestibility compared with the control diet (Table 3).

Milk from cows fed the control diet (CG-SBM) had the lowest fat and highest lactose content, whereas cows fed SBP-DDGS produced lower yields of protein (Table 4). No differences in yield of milk and yield of ECM were observed among the different treatments. We found no differences in the effect of the different diets on cow BW or BCS.

The control diet CG-SBM was less efficient in terms of HeFCE and net food production compared with the by-product-based diets (Table 5). The net production of human-edible CP and gross energy was negative in the control diet. The SBP-DDGS diet showed the highest efficiency of net production of HDEAA (Figure 1).

\section{DISCUSSION}

We investigated the effects on performance and feed efficiency traits when high-yielding dairy cows were fed diets based on by-products and forage compared with a conventional concentrate mixture based on CG-SBM together with forage. The results suggested that total food production can increase if dairy cows are fed byproducts compared with conventional concentrate.

Sustainable feeding strategies in dairy production can be compared in different ways. One way is to calculate 
Table 4. Mean treatment effects on daily yield of milk, ECM, milk components, and milk composition for the 4 different concentrates (LSM with SEM and $P$-value)

\begin{tabular}{|c|c|c|c|c|c|c|}
\hline \multirow[b]{2}{*}{ Item } & \multicolumn{4}{|c|}{ Diet $^{1}$} & \multirow[b]{2}{*}{ SEM } & \multirow{2}{*}{$\begin{array}{c}P \text {-value } \\
\text { Treatment }\end{array}$} \\
\hline & $\begin{array}{c}\text { CG-SBM } \\
\text { (control) }\end{array}$ & SBP-DDGS & SBP-RSM & SBP-RSM-DDGS & & \\
\hline \multicolumn{7}{|c|}{ Yield, $\mathrm{kg} / \mathrm{d}$} \\
\hline Milk & 32.1 & 30.8 & 32.0 & 31.9 & 0.90 & 0.059 \\
\hline $\mathrm{ECM}^{2}$ & 33.1 & 32.4 & 33.7 & 33.3 & 0.88 & 0.170 \\
\hline Fat & 1.36 & 1.39 & 1.42 & 1.40 & 0.04 & 0.457 \\
\hline \multicolumn{7}{|c|}{ Concentration, \% } \\
\hline Fat & $4.27^{\mathrm{b}}$ & $4.57^{\mathrm{a}}$ & $4.47^{\mathrm{ab}}$ & $4.46^{\mathrm{ab}}$ & 0.10 & 0.029 \\
\hline Protein & 3.42 & 3.35 & 3.38 & 3.39 & 0.05 & 0.237 \\
\hline Lactose & $4.59^{\mathrm{a}}$ & $4.55^{\mathrm{b}}$ & $4.54^{\mathrm{b}}$ & $4.53^{\mathrm{b}}$ & 0.03 & 0.004 \\
\hline
\end{tabular}

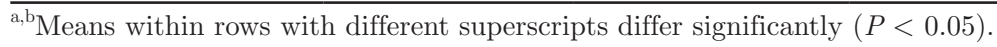

${ }^{1} \mathrm{CG}=$ cereal grain; $\mathrm{SBM}=$ soybean meal; $\mathrm{SBP}=$ sugar beet pulp; DDGS $=$ distillers grain; $\mathrm{RSM}=$ rapeseed meal.

${ }^{2}$ Calculated according to Sjaunja et al. (1990).

the feed conversion efficiency ( $\mathrm{kg}$ of ECM divided by $\mathrm{kg}$ of DMI) to find the most efficient production. We found no differences in feed conversion efficiency between the treatments in the present study (Table 5). However, with this approach, no consideration was given to what the animals are fed, only how much. Another way to compare diets from a sustainability point of view is to estimate the amount of human edibles produced in comparison with the amount of human edibles fed (Wilkinson, 2011; Ertl et al., 2016; Patel et al., 2017a). Diets based on forage and by-products normally score high when examining production efficiency for human edibles, and this was also the case in the present study, where the by-product-based diets had higher net food production and HeFCE for both energy and protein than the control diet (Table 5). Hence, in relation to the input, diets with by-product-based concentrates generate higher net production of human-edible protein and energy than conventional concentrates based on CG and SBM. The efficiency was low on the control diet, even though the cows consumed almost $60 \%$ forage, which is assumed not to contain any human edibles at all. The control diet actually generated negative net food production values.

The cows on diets with by-products as concentrate produced as much milk as the cows fed conventional concentrate based on CG-SBM, and we observed no differences in silage intake and DMI between the diets. This is in agreement with findings in several previous studies comparing CG or SBM, or both, to different by-products, such as SBP and wheat bran (Dann et al., 2014; Ertl et al., 2016), DDGS (Anderson et al., 2006),

Table 5. Effect of treatment on the efficiency parameters feed conversion efficiency, human edibles efficiency, and net food production (LSM with SEM and $P$-value)

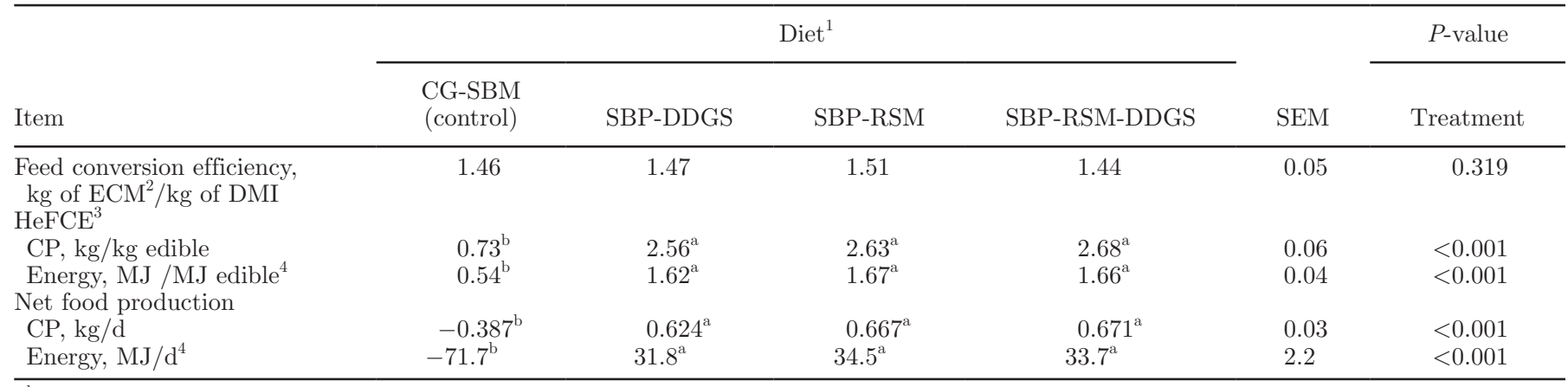

\footnotetext{
${ }_{\mathrm{a}, \mathrm{b}}$ Means within rows with different superscripts differ significantly $(P<0.05)$.

${ }^{1} \mathrm{CG}=$ cereal grain; $\mathrm{SBM}=$ soybean meal; $\mathrm{SBP}=$ sugar beet pulp; DDGS $=$ distillers grain; $\mathrm{RSM}=$ rapeseed meal

${ }^{2}$ Energy-corrected milk, calculated according to Sjaunja et al. (1990).

${ }^{3}$ Human-edible feed conversion efficiency (HeFCE).

${ }^{4} \mathrm{MJ}$ of gross energy.
} 


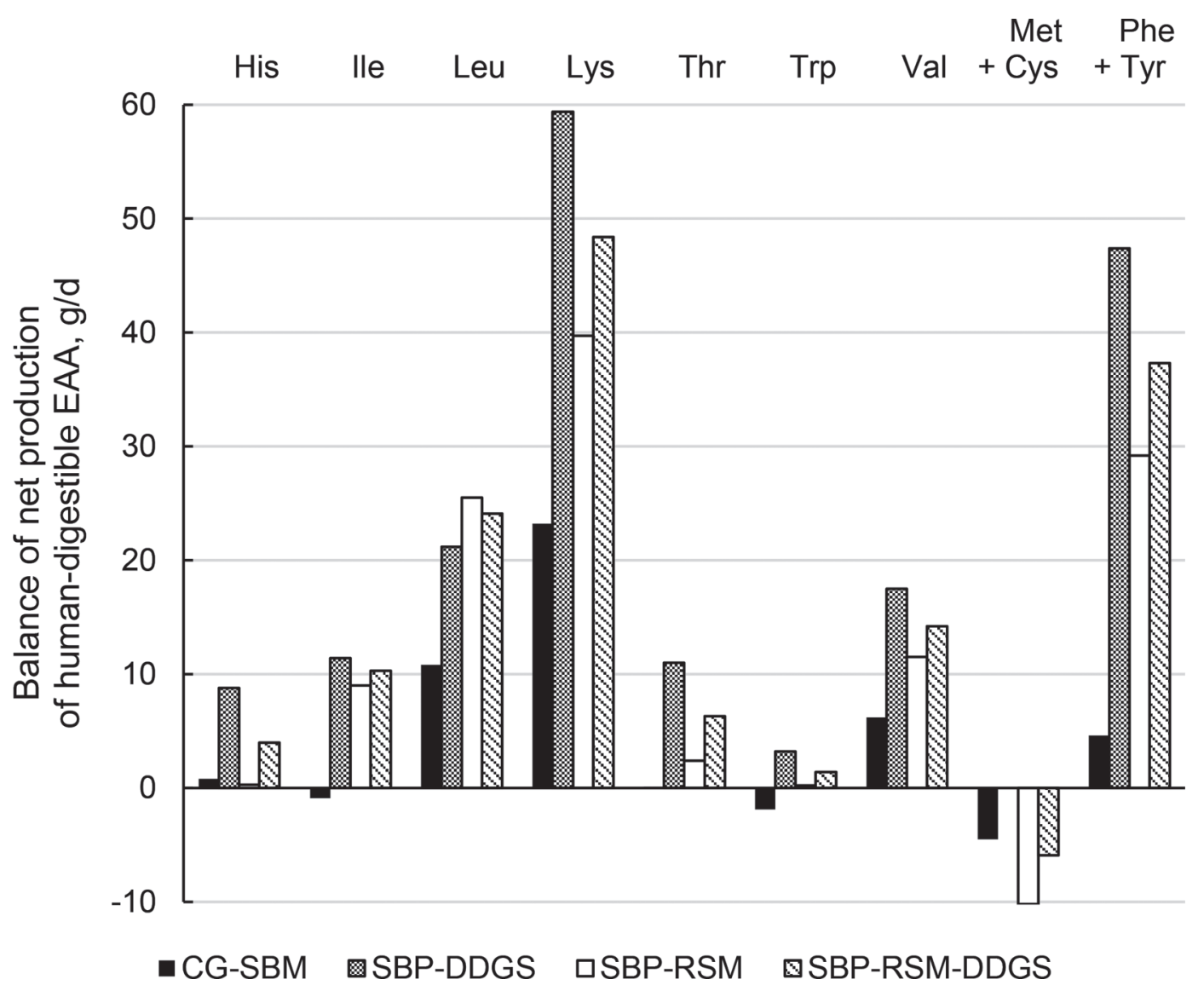

Figure 1. Estimated balance of net production of human-digestible EAA from milk produced minus human-edible feeds fed (g/d) for different diets: cereal grain, soybean meal (CG-SBM), sugar beet pulp, distillers grain (SBP-DDGS), sugar beet pulp, rapeseed meal (SBP-RSM), and sugar beet pulp, rapeseed meal, distillers grain (SBP-RSM-DDGS).

or RSM and DDGS (Maxin et al., 2013). In the control diet in the present study, SBM was the main protein source in the concentrate. In the by-product-based concentrates, RSM or DDGS, or both, mainly contributed to the protein content. Based on meta-analyses, Huhtanen et al. (2011) and Martineau et al. (2013) concluded that milk production is usually greater in cows fed a diet containing RSM compared with other protein sources, such as SBM. However, in the present study, no differences in milk production were observed between the treatments. In contrast, Anderson et al. (2006) reported higher milk and ECM yields on a diet with DDGS compared with SBM.

Cows that were fed a by-product-based diet consumed $<0.4 \mathrm{~kg}$ of starch $/ \mathrm{d}$, whereas cows fed the control diet consumed about 10-fold more starch $(4.0 \mathrm{~kg} / \mathrm{d}$; Table $3)$. When fed the by-product diets, the cows consumed around $40 \% \mathrm{NDF}$ in total $\mathrm{DM}$ and produced equal amounts of milk to cows fed the control diet (33\% NDF in total DM, based on Table 1 and Table 4). Whelan et al. (2017) also fed concentrates with by-product, starch, and NDF contents similar to those in the present study and saw no effect on feed intake or milk production in a pasture-based system. Moreover, replacing starch rich grain with fiber-rich by-products in dairy cows diets would reduce the risk of acidosis (Krause and Oetzel, 2006). Around $25 \%$ of the DM in the by-product-based concentrates in the present study were not accounted for in the chemical analyses. In contrast, only around $17 \%$ of DM was not accounted for in the control concentrate CG-SBM. The by-product-based concentrates had a SBP content of 50 to $53 \%$ of DM (Table 2), which provides ruminants with rumen-fermentable carbohydrates other than starch (Chase, 2007). Most of the unknown compounds in the by-product-based concentrates were probably pectin and other carbohydrate sources that were not included in the NDF fraction of the feed (Udén, 2017).

No differences were observed in yield of ECM or in the concentration of protein in the milk, as in previous studies (Maxin et al., 2013; Dann et al., 2014; Ertl et al., 2016); however, the present study lacks by power to 
identify treatment effects on yield below $2 \mathrm{~kg}$ of ECM. The concentrate proportion in the diets of the present study was $40 \%$. It cannot be excluded that the results would have been different if the cows were offered a higher concentrate proportion. The overall level of ECM yield in the present study was higher than in the studies by Maxin et al. (2013) and Ertl et al. (2015, 2016); this could be explained by lactation stage, breeds, or different nutritional factors. Interestingly, previous calculations of HeFCE for protein showed that lower milk production gave higher protein conversion efficiency for all diets compared (Swensson et al., 2017). Similarly, Patel et al. (2017a) found that a low-yielding and more extensive dairy production system was also the most efficient with regard to both protein and EAA. As for some other sustainability aspects of milk production, relatively high production levels are desirable, as this is one of the most effective ways to reduce, for example, methane emissions per kilogram of product (Hristov et al., 2013). However, high-fiber diets could lead to greater enteric methane production and a higher fat concentration in the milk as a result of increasing proportions of acetate at fermentation (Van Soest, 1994). However, methane emissions from enteric fermentation is far from the only impact dairy cows have on the environment. Under Swedish conditions feed production for cattle cause a greater impact on greenhouse gas emissions than enteric fermentation (Flygsjö et al., 2011). Moreover, land use $\left(\mathrm{m}^{2} / \mathrm{kg}\right.$ of $\left.\mathrm{DM}\right)$ is generally lower for different by-products than for crop grown solely as feed because the land area is allocated between both main crop and by-products (Henriksson et al., 2014).

We noted an overall effect of diet on milk fat concentration, but the milk fat concentration was significantly higher relative to CG-SBM only for cows consuming the SBP-DDGS diet (Table 4), although the differences in fat concentration did not cause significant differences in fat yield or ECM. Relative to other studies (Aguerre et al., 2011; Sterk et al., 2011; Argov-Argaman et al., 2014; Patel et al., 2017b), greater differences in fat production might have been expected considering the large differences in NDF and starch content between the control diet and the by-product-based diets. However, in other studies, no effect on milk fat concentration was observed when replacing CG or SBM with different by-products (Anderson et al., 2006; Maxin et al., 2013; Dann et al., 2014; Ertl et al., 2016; Mutsvangwa et al., 2016). Although the diet with DDGS as the main protein source generated a higher milk fat concentration, daily milk fat yield did not differ due to numerically lower milk production among cows fed the diet with SBP-DDGS concentrate.

Cows on the control diet consumed more humanedible protein and energy than they produced in the milk because SBM and CG are considered high-quality protein and energy sources for humans. When comparing the net production of separate HDEAA, the diet with SBP-DDGS improved protein quality the most, as DDGS has low protein quality relative to SBM and RSM (Figure 1). Overall, the control diet with CGSBM concentrate was found to be the least efficient with regard to improving protein quality, and actually showed negative HDEAA net production values for isoleucine, tryptophan, and methionine + cysteine. One could argue that it is more sustainable to feed SBM and CG directly to humans instead of feeding it to animals and losing net production of human-edible protein and HDEAA. Not all sustainability aspects were taken in consideration when comparing sustainable feeding strategies from a human-edible perspective, but the current study is an important first step. Future studies should cover other sustainability aspects; for example, using life cycle assessment and land use ratio (Van Zanten et al., 2016).

\section{CONCLUSIONS}

Replacing CG and SBM with SBP in combination with RSM, DDGS, or RSM and DDGS in the diet of high-yielding dairy cows in mid-lactation did not affect feed intake or milk production when fed together with high-quality grass silage. As expected, the efficiency of human food production was substantially higher on replacing CG and SBM with the human-inedible agricultural by-products used in the present study.

\section{ACKNOWLEDGMENTS}

The authors thank the staff at the Swedish Livestock Research Centre (Uppsala, Sweden) for managing the animals, the laboratory staff at the Department of Animal Nutrition and Management for the laboratory analyses, and Rainer Nylund at the Division of Feed Science at the Department of Animal Nutrition and Management for preparing the silage. This study was funded by the research program AquaAgri, which is jointly funded by Formas (Stockholm, Sweden), Mistra (Stockholm, Sweden), and Lantmännen (Stockholm, Sweden).

\section{REFERENCES}

Argov-Argaman, N., R. Mesilati-Stahy, Y. Magen, and U. Moallem. 2014. Elevated concentrate-to-forage ratio in dairy cow rations is associated with a shift in the diameter of milk fat globules and remodelling of their membranes. J. Dairy Sci. 97:6286-6295. https:// doi.org/10.3168/jds.2014-8174.

Aguerre, M. J., M. A. Wattiaux, J. M. Powell, G. A. Broderick, and C. Arndt. 2011. Effect of forage-to-concentrate ratio in dairy cow diets on emission of methane, carbon dioxide, and ammonia, lacta- 
tion performance, and manure excretion. J. Dairy Sci. 94:30813093. https://doi.org/10.3168/jds.2010-4011.

Åkerlind, M., M. Weisbjerg, T. Eriksson, P. Udén, B. L. Ólafsson, O. Harstad, and H. Volden. 2011. Feed analyses and digestion methods. Pages 41-54 in NorFor-The Nordic Feed Evaluation System. Vol. 130. H. Volden, ed. Wageningen Academic Publishers. Wageningen, the Netherlands. https://doi.org/10.3920/978-90 -8686-718-9.

Anderson, J. L., D. J. Schingoethe, K. F. Kalscheur, and A. R. Hippen. 2006. Evaluation of dried and wet distillers grains included at two concentrations in the diets of lactating dairy cows. J. Dairy Sci 89:3133-3142. https://doi.org/10.3168/jds.S0022-0302(06)72587 -5 .

Bhattacharya, A. N., and F. T. Sleiman. 1971. Beet pulp as a grain replacement for dairy cows and sheep. J. Dairy Sci. 54:89-94. https://doi.org/10.3168/jds.S0022-0302(71)85783-1.

Broderick, G. A., and J. H. Kang. 1980. Automated simultaneous determination of ammonia and total amino acids in ruminal fluid and in vitro media. J. Dairy Sci. 63:64-75. https://doi.org/10 .3168/jds.S0022-0302(80)82888-8.

Chai, W. H., and P. Udén. 1998. An alternative oven method combined with different detergent strengths in the analysis of neutral detergent fibre. Anim. Feed Sci. Technol. 74:281-288. https://doi .org/10.1016/S0377-8401(98)00187-4.

Chase, L. E. 2007. Can we feed less starch to our cows? Pages 213-220 in Proc. Cornell Nutr. Conf. Feed Manuf., East Syracuse, NY. Cornell Univ., Ithaca, NY.

CVB Feed Table. 2011. Chemical Composition and Nutritional Values of Feed Materials. PDV, Zoetermeer, the Netherlands.

Dann, H. M., H. A. Tucker, K. W. Cotanch, P. D. Krawczel, C. S. Mooney, R. J. Grant, and T. Eguchi. 2014. Evaluation of lower-starch diets for lactating Holstein dairy cows. J. Dairy Sci. 97:7151-7161. https://doi.org/10.3168/jds.2014-8341.

Edmonson, A. J., I. J. Lean, L. D. Weaver, T. Farver, and G. Webster. 1989. A body condition scoring chart for Holstein dairy cows. J. Dairy Sci. 89:68-78. https://doi.org/10.3168/jds.S0022 -0302(89)79081-0.

Eisler, M. C., M. R. F. Lee, J. F. Tarlton, G. B. Martin, J. Beddington, J. A. J. Dungait, H. Greathead, J. Liu, S. Mathew, H. Miller, T. Misselbrook, P. Murray, V. K. Vinod, R. Van Saun, and M. Winter. 2014. Steps to sustainable livestock. Nature 507:32-34. https://doi.org/10.1038/507032a.

Ericson, B., and J. André. 2010. HPLC-Applications for agricultura and animal science. Pages 23-26 in Proc. of the 1st Nordic Feed Science Conference, Uppsala, Sweden. The Swedish University of Agricultural Science, Uppsala, Sweden.

Ertl, P., Q. Zebeli, W. Zollitsch, and W. Knaus. 2015. Feeding of byproducts completely replaced cereals and pulses in dairy cows and enhanced edible feed conversion ratio. J. Dairy Sci. 98:1225-1233. https://doi.org/10.3168/jds.2014-8810.

Ertl, P., Q. Zebeli, W. Zollitsch, and W. Knaus. 2016. Feeding of wheat bran and sugar beet pulp as sole supplements in high-forage diets emphasizes the potential of dairy cattle for human food supply. J. Dairy Sci. 99:1228-1236. https://doi.org/10.3168/jds.2015 -10285 .

European Economic Community. 1998. Corrigendum to Commission Directive 98/64/EC of 3 September 1998 establishing Community methods of analysis for the determination of amino-acids, crude oils and fats, and olaquindox in feedingstuffs and amending Directive 71/393/EEC. Off. J. L275:14-28.

FAO. 2009. The state of food and agriculture. Livestock in balance. FAO, Rome, Italy.

FAO. 2011. World Livestock 2011—Livestock in Food Security. FAO, Rome, Italy.

FAO. 2013. Dietary protein quality evaluation in human nutrition. FAO Food Nutr. Pap. 92:1-66 (FAO, Rome, Italy.).

Flygsjö, A., M. Henriksson, C. Cederberg, S. Ledgard, and J. E. Englund. 2011. The impact of various parameters on the carbon footprint of milk production in New Zealand and Sweden. Agric. Syst. 104:459-469. https://doi.org/10.1016/j.agsy.2011.03.003.
Foley, J. A., N. Ramankutty, K. A. Brauman, E. S. Cassidy, J. S. Greber, M. Johnston, N. D. Mueller, C. O'Connell, D. K. Ray, P. C. West, C. Balzer, E. M. Bennett, S. R. Carpenter, J. Hill, C. Monfreda, S. Polasky, J. Rockström, J. Sheehan, S. Sibert, D. Tilman, and D. P. M. Zaks. 2011. Solutions for a cultivated planet. Nature 478:337-342. https://doi.org/10.1038/nature10452.

Henriksson, M., C. Cederberg, and C. Swensson. 2014. Carbon footprint and land requirement for dairy herd rations: impacts of feed production practices and regional climate variations. Animal 8:1329-1338. https://doi.org/10.1017/S1751731114000627.

Hristov, A. N., T. Ott, J. Tricarico, A. Rotz, G. Waghorn, A. Adesogan, J. Dijkstra, F. Montes, J. Oh, E. Kebreab, S. J. Oosting, P. J. Gerber, B. Henderson, H. P. Makkar, and J. L. Firkins. 2013. Mitigation of methane and nitrous oxide emissions from animal operations: III. A review of animal management mitigation options. J. Anim. Sci. 91:5095-5113. https://doi.org/10.2527/jas .2013-6585.

Huhtanen, P., M. Hetta, and C. Swensson. 2011. Evaluation of canola meal as a protein supplement for dairy cows: A review and a metaanalysis. Can. J. Anim. Sci. 91:529-543. https://doi.org/10.4141/ CJAS2011-029.

INRA, CIRAD, AFZ, and FAO. 2016. Feedipedia-Animal Feed Resources Information System. Accessed Nov. 25, 2016. http:// feedipedia.org

IPCC. 2014. Introductory chapter. Pages 111-150 in Climate Change 2014: Mitigation of Climate Change. Contribution of Working Group III to the Fifth Assessment Report of the Intergovernmental Panel on Climate Change. O. Edenhofer, R. Pichs-Madruga, Y. Sokona, E. Farahani, S. Kadner, K. Seyboth, A. Adler, I. Baum, S. Brunner, P. Eickemeier, B. Kriemann, J. Savolainen, S. Schlömer, C. von Stechow, T. Zwickel, and J. C. Minx, ed. Cambridge University Press, Cambridge, UK. https://doi.org/10.1017/ CBO9781107415416.007.

Larsson, K., and S. Bengtsson. 1983. Determination of non-structura carbohydrates in plant material. Method description n. 22. National Laboratory for Agricultural Chemistry, Uppsala, Sweden. [In Swedish]

Krause, K. M., and G. R. Oetzel. 2006. Understanding and preventing subacute ruminal acidosis in dairy herds: A review. Anim. Feed Sci. Technol. 126:215-236. https://doi.org/10.1016/j.anifeedsci .2005.08.004.

Martineau, R., D. R. Ouellet, and H. Lapierre. 2013. Feeding canola meal to dairy cows: A meta-analysis on lactational responses. J. Dairy Sci. 96:1701-1714. https://doi.org/10.3168/jds.2012-5740.

Maxin, G., D. R. Ouellet, and H. Lapierre. 2013. Effect of substitution of soybean meal by canola meal or distillers grains in dairy rations on amino acid and glucose availability. J. Dairy Sci. 96:7806-7817. https://doi.org/10.3168/jds.2013-6976.

Mutsvangwa, T., D. Kiran, and S. Abeysekara. 2016. Effects of feeding canola meal or wheat dried distillers grains with solubles as a major protein source in low- or high-crude protein diets on ruminal fermentation, omasal flow, and production in cows. J. Dairy Sci. 99:1216-1227. https://doi.org/10.3168/jds.2015-9991.

Patel, M., U. Sonesson, and A. Hessle. 2017a. Upgrading plant amino acids trough cattle to improve the nutritional value for humans: effects of different production systems. Animal 11:519-528. https:// doi.org/10.1017/S1751731116001610.

Patel, M., E. Wredle, E. Spörndly, and J. Bertilsson. 2017b. Whole lactation production responses in high-yielding dairy cows using high-quality grass/clover silage. J. Sci. Food Agric. 97:2883-2890. https://doi.org/10.1002/jsfa.8119.

Schingoethe, D. J., K. F. Kalscheur, A. R. Hippen, and A. D. Garcia. 2009. Invited review: The use of distillers products in dairy cattle diets. J. Dairy Sci. 92:5802-5813. https://doi.org/10.3168/ jds.2009-2549.

Sjaunja, L. O., L. Baevre, L. Junkkarinen, J. Pedersen, and J. Setälä. 1990. A Nordic proposal for an energy corrected milk (ECM) for mula. Pages 156-192 in Performance Recording of Animals: 27th Biennial Session of the International Committee of Animal Recording, Paris, France. EAAP publication No. 50. Center for Ag- 
ricultural Publishing and Documentation (Pudoc), Wageningen, the Netherlands.

SJVFS. 2011. 2011:40, Saknr M39. Code of Statutes, Regulations and common advice concerning feed. The Swedish Board of Agriculture, Jönköping, Sweden. [In Swedish].

Sterk, A., B. E. Johansson, H. Z. Taweel, M. Murphy, A. M. van Vuuren, W. H. Hendriks, and J. Dijkstra. 2011. Effects of forage type, forage to concentrate ratio, and crushed linseed supplementation on milk fatty acid profile in lactating dairy cows. J. Dairy Sci. 94:6078-6091. https://doi.org/10.3168/jds.2011-4617.

Swensson, C., H. Lindmark-Månsson, A. Smedman, M. Henriksson, and A. K. Modin Edman. 2017. Protein efficiency in intensive dairy production: A Swedish example. J. Sci. Food Agric. 97:48904897. https://doi.org/10.1002/jsfa.8362.

Udén, P. 2017. Fresh and ensiled forage plants-Total composition, silage losses and the prediction of silage composition from the crop. Grass Forage Sci. 00:1-12. https://doi.org/10.1111/gfs.12328.

USDA. 2016. National nutrient database for standard reference, release 28. Accessed Nov. 25, 2016. https://ndb.nal.usda.gov

Van Keulen. J., and B. A. Young. 1977. Evaluation of acid-insoluble ash as a natural marker in ruminant digestibility studies. J. Anim. Sci. 44:282-287. https://doi.org/10.2527/jas1977.442282x.

Van Soest, P. J. 1994. Nutritional Ecology of the Ruminant. Cornell University Press, Ithaca, NY.
Van Zanten, H. H. E., H. Mollenhorst, C. W. Klootwijk, C. E. van Middelaar, and I. J. M. de Boer. 2016. Global food supply: Land use efficiency of livestock systems. Int. J. Life Cycle Assess. 21:747-758. https://doi.org/10.1007/s11367-015-0944-1.

Voelker, J. A., and M. S. Allen. 2003. Pelleted beet pulp substituted for high-moisture corn: 1. Effects on feed intake, chewing behavior, and milk production of lactating dairy cows. J. Dairy Sci. 86:35423552. https://doi.org/10.3168/jds.S0022-0302(03)73959-9.

Volden. H., and N. I. Nielsen. 2011. Energy and metabolizable protein supply. Pages 81-84 in NorFor-The Nordic Feed Evaluation System. Vol. 130. H. Volden, ed. Wageningen Academic Publishers, Wageningen, the Netherlands. https://doi.org/10.3920/978-90 -8686-718-9.

Whelan, S. J., W. Carey, T. M. Boland, M. B. Lynch, A. K. Kelly, G. Rajauria, and K. M. Pierce. 2017. The effect of by-product inclusion level on milk production, nutrient digestibility and excretion, and rumen fermentation parameters in lactating dairy cows offered a pasture-based diet. J. Dairy Sci. 100:1055-1062. https://doi.org/ $10.3168 /$ jds.2016-11600.

Wilkinson. J. M. 2011. Re-defining efficiency of feed use by livestock. Animal 5:1014-1022. https://doi.org/10.1017/S175173111100005X. 